\title{
D-8 NORIAN CARBONATE PLATFORM AND RELATED BASINS - AN EXAMPLE FROM THE EAST LOMBARDY SOUTHERN ALPS, ITALY
}

P. RONCHI ${ }^{1}$, R. FANTONI ${ }^{1}$, P. SCOTTI ${ }^{1}$, G.L. TROMBETTA ${ }^{2}$ and D. MASETTI ${ }^{2}$

${ }^{1}$ Eni SpA Agip Division, Via Emilia 1, 20097 San Donato Milanese, Italy ${ }^{2}$ Ferrara University

The Upper Triassic succession of the Lombardy Basin includes petroleum systems composed of carbonate platform reservoirs and intraplatform basin source rocks. These systems are proved to be efficient in the subsurface oil fields of the Po Valley.

During Norian time the Southern Alps were seated at the northern margin of the Adria Microplate, in the westernmost part of the Tethys sea way. The wide carbonate depositional systems were involved in a extensional tectonic regime (Jadoul, 1985) which preluded the Middle Jurassic Ligurian-Piedmont ocean opening (Gaetani, 1976, Winterer and Bosellini, 1981, Bertotti et al. 1996). In the Lombardy Basin, the thick Norian Dolomia Principale carbonate platform was affected by this tectonics, which caused the formation of half grabens where thick laminated carbonates and black shales were deposited (Jadoul et al., 1992, Jadoul et al., 1994). The dolomitic platform, its margin facies and the upper slope breccia bodies constitute the potential reservoir, while in the oxygen deficient intraplatform basins, thick organic matter rich successions provide hydrocarbon source.

This work focus on a few Km wide Norian depositional system of the easternmost Lombardy basin (Fig. 1). The integrated sedimentologic, diagenetic and geochemical study of the platform and basin succession allowed to reconstruct the hydrocarbon potential of this relatively small petroleum system that resulted interesting from exploration point of view.

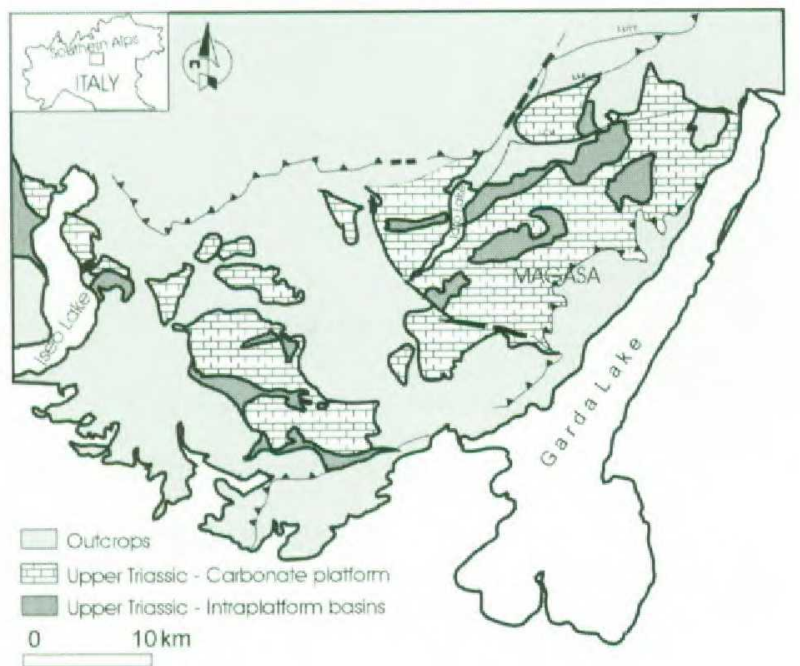

Fig. 1 - Location map of the intraplatform basins in the Norian period.

The studied area, located between the Iseo and Garda lakes, belongs to the Giudicarie deformed belt of the central Southern Alps. Nevertheless the weak deformation inside a large SE vergent thrust, allowed the preservation of the original geometry of the Norian depositional system.

In the half graben of Magasa-Capovalle Basin, developed inside the Dolomia Principale (Trombetta and Bottoni 1993), different sectors have been detected according to their paleoenvironmental significance and sedimentary evolution (Fig. 2). The basin is bounded southward by synsedimentary faults, while the northern margin 
is a flexural one, where huge clinoform breccia bodies interfingered southward with the basinal fine grained carbonate deposits (Facies Eteropiche and Zorzino Limestone); furthermore, the extensional paleotectonic controlled the different evolution of various sectors in the basin.

The field work and regional geologic model allowed to reconstruct four sedimentary steps in the development of the basin (Fig. 3).

1) The basal interval is represented by the Lower Member of the Dolomia Principale, widespread on the whole area, and the Lower Member of the Facies Eteropiche which were confined in the footwall of the extension fault of the southern area. The Dolomia Principale is mainly made of subtidal facies which were early dolomitized; the Facies Eteropiche are made of turbiditic limestones and breccia-megabreccia bodies caused by the tectonic pulse that dismantled and reworked platform and slope deposits.

2) During the subsequent tectonic extension the basin widened and was progressively filled up by the Facies Eteropiche and, in the central part of the basin, by thin bedded dark facies of the Zorzino Limestone. In the northern flexural flank, the geometry of the breccia clinoforms suggests the progradational setting of the platform, linked to the progressive filling up of the basin in the overall shallowing upward sequence. Several serpulid-microbialitic mounds are intercalated within the slope deposits which consist of thickening upward cycles of turbiditic and breccia sediments. The mounds shape is usually plane-convex and their size is strongly variable, ranging from few to several tens of meters of length and up to 10 meters high (Trombetta et al.,2000).

On the structural highs the Upper Member of the Dolomia Principale facies association includes low and high energy subtidal deposits and peritidal ones. The series shows an overall regressive trend, that grades from high energy subtidal cycles to mainly peritidal cycles, with tepee horizons in the uppermost part of the formation.

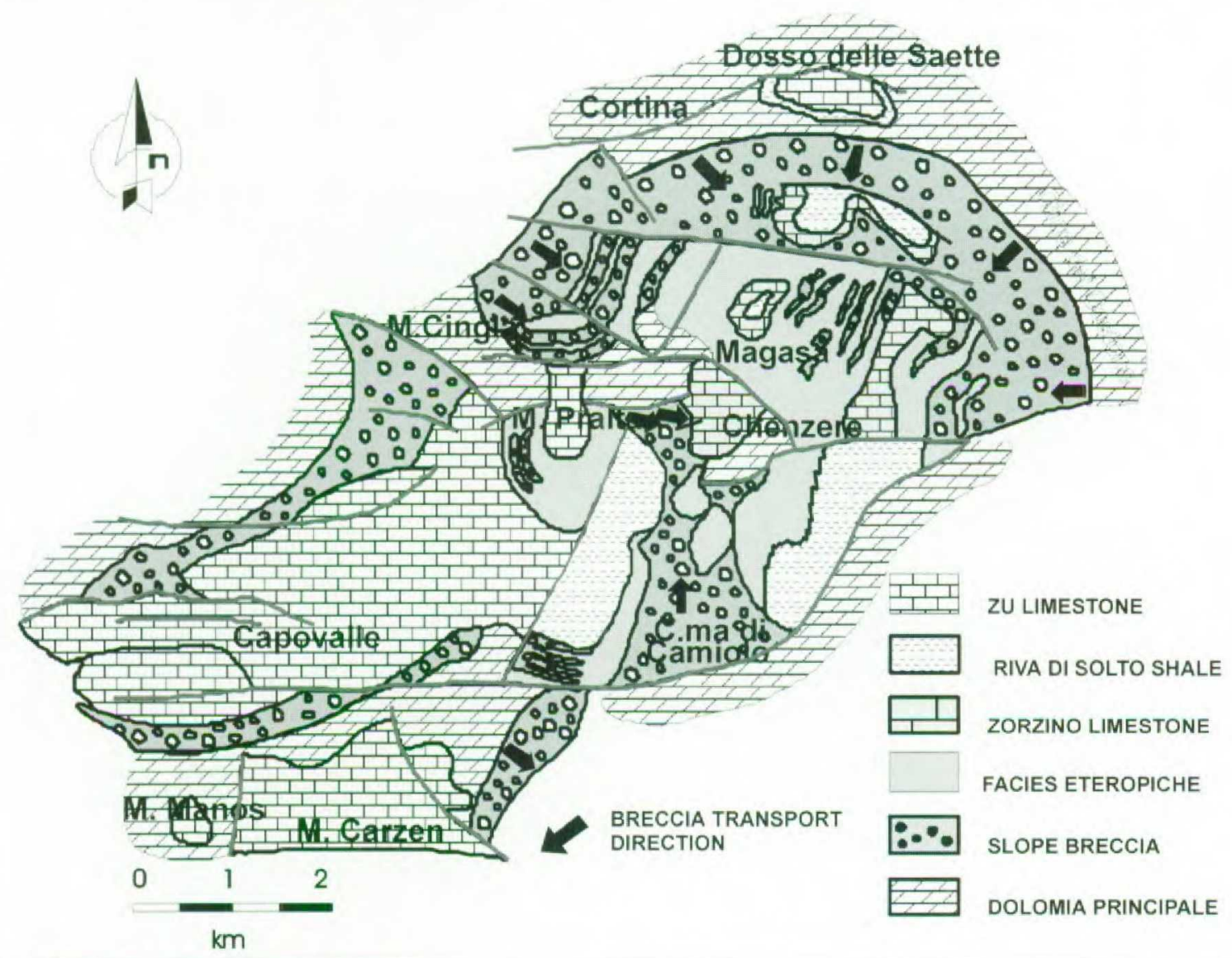

Fig. 2 - Geological map of Magasa basin

3) A third step of the basin is represented by the end of the carbonate platform growth, which probably locally underwent subaerial exposure in the higher sector of the platform. Evidences of emersion are: reddened surface with small pockets filled by red shale, mudstones nodules and iron oxides and negative values of $\square{ }^{13} \mathrm{C}$ which suggest a fresh water diagenesis. During this phase the central part of the basin started to be filled up by dark gray, thin bedded limestones and marls of the upper lithozone of the Zorzino Limestone. 
4) The last basin filling phase is represented by the Riva di Solto Shale Formation deposition, which is connected to a new paleogeographic regional setting that was marked by the influx in the depositional system of large quantities of fine grained terrigenous from the North. These shaly sediments onlappped on the paleostructural highs of the Dolomia Principale and filled up the previous morphologic irregularities; the formation shows the thinnest thickness in the northermost platform area and the highest ones in the depocentre.

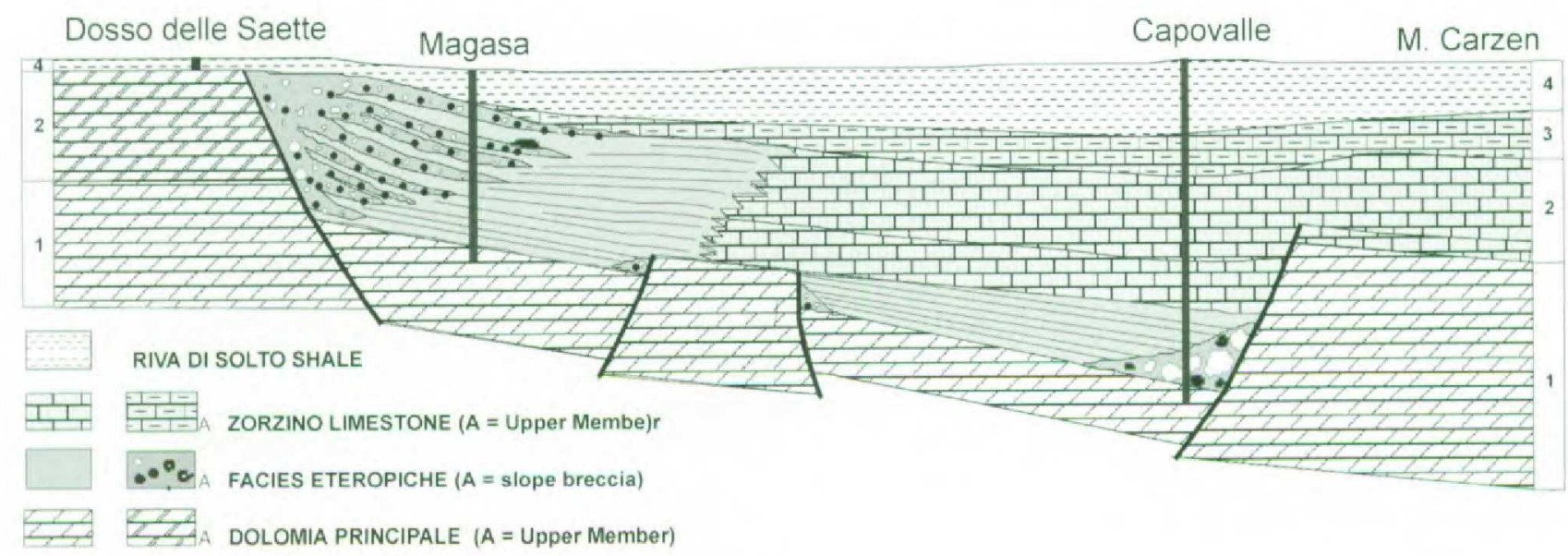

\section{Fig. 3 - Geological cross section of the Magasa basin}

The diagenetic study and petrophysical properties evaluation carried out on the platform and upper slope facies brought the following considerations. The Dolomia Principale shows early diagenesis and dolomitization and only local recrystallization occurred in burial environment. This diagenetic evolution brought to early cementation of the primary porosity and therefore its values are of few percentage units (about $4-5 \%$ ). Secondary porosity, which developed during burial, reaches higher values: it is related to fractures, dissolution vugs and intercrystalline pores. Breccia slope bodies shows higher porosity values up to $10-12 \%$ due to molds and intergranular vugs. The diagenetic study of the fine breccia rudstones, which included petrography observations and stable isotopic analyses, allowed to infer that along the upper slope some meteoric derived waters fluxed the system. These aggressive waters produced selective pores hat locally can reach centimetre size. This event should be correlated with emersion of the Dolomia Principale at the end of its shallowing up sequence.

The serpulid mound facies association underwent an early cementation that destroyed the framework primary porosity, and only in presence of late diagenetic dissolution and fracturation could be condidered as reservoir rocks. Geochemical analyses, including T.O.C., rock-eval and optical analyses, performed on several samples of two basinal series in the Magasa-Capovalle basin, integrated with data coming from surrounding basins, allowed to evaluate the hydrocarbon potential of the basin.

$\mathrm{T}_{\max }, \mathrm{TAI}$ and $\mathrm{R}_{\mathrm{o}}$ values indicate high maturity of the samples, with overcoming of the oil window. Therefore the measured values of source rock properties of these samples are largely depleted with respect to the original ones. The residual T.O.C., variable in the different lithofacies, is usually correlated to the clay content with the exception of the Zorzino Limestone which shows good organic matter content also in the dark grey micritic limestone layers. Riva di Solto Shales shows the richest T.O.C. values, with a type III kerogen, while in the Zorzino Limestone no immmature/early mature samples have been found in the area and it is likely that the kerogen quality was better (type II kerogen).

The Facies Eteropiche shows only few thin layers with a good T.O.C., but they are too rare in the whole sedimentary section in order to make the formation interesting from the source rock point of you.

Considering these source rock properties and the thickness of the Riva di Solto Shale and the upper part of the Zorzino Limestone, that reaches more than $550 \mathrm{~m}$ in the depocentre, we can estimate a good original Source Potential Index (SPI, ton $\mathrm{HC} / \mathrm{m}^{2}$ ) for the Magasa basin; thus the average hydrocarbon quantity that could have been generated in the drainage area (about $30 \mathrm{Km}^{2}$ ) is sufficient to be considered of industrial interest.

These results pointed out that these Norian extension carbonate basin-platform systems could be efficient petroleum systems also if they are of small dimensions. This favourable explorative pattern is provided by the good source potential index of the euxinic basin sediments, the high drainage efficiency due to the direct contact between the source and the reservoir rocks (slope breccia represent carrier and reservoir units) and the ovelying shaly formation represents the sealing of the system. 
The documented presence in the western Southern Alps of several and locally wider Norian intraplatform basins with regional NS direction represent an exploration target in the external structures of the thrusts folded belts and in the Po Valley foreland.

\section{Cited References}

Bertotti G., Picotti V., Bernoulli D., Castellarin A., 1993. From Rifting to drifting: tectonic evolution of the South-Alpine upper crust from the Triassic to the Early Cretaceous. Sedimentary Geology, 86, pp.53-76.

GaETANI M., 1976. Jurassic stratigraphy of the Southern Alps: a review. In: C.Squyers (Editor), Geology of Italy. Earth Sci. Soc. Lybian Arab Republic, pp. 377-402.

Jadoul F., Masetti D., Cirilli S., Berra F., Claps M. aNd Frisia S. ,1994. Norian-Rhaetian stratigraphy and paleogeographic evolution of the Lombardian Basin. - 15th IAS regional meeting, April 1994, Ischia Italy Excursion B 1.

JADOUL F., BerRa F. AND Frisia S., 1992. Stratigraphic evolution of a carbonate platform in an extensional tectonic regime: the example of the Dolomia Principale in Lombardy (Italy) - Riv. Ital. Paleont. Strat., 98/1, 2944.

JADOUL F., 1985. Stratigrafia e paleogeografia del Norico nelle Prealpi Bergamasche accidentali - Riv. It. Paleont. Strat, 91/4, 479-512.

TrombetTA G.L. AND BotToNi D., 1993. Analisi di facies ed evoluzione in 3D di un bacino intrapiattaforma del Norico della lombardia (Valvestino, Prealpi Bresciane). - Mem. Sci. Geol., 45, 149-164.

Trombetta G.L., Ronchi P., Masetti D. aNd T. RicchiUto (2000). Serpulid and microbial mounds of the platform-basin transition: an example from the Norian of the Southern Alps (Lombardy Basin, Italy). Abstract. Soc.' Geol. It. $80^{\circ}$ Ruunione Estiva. Trieste 2000.

WiNTERER E.L., BoSELliNi A., 1981: Subsidence and sedimentation in Jurassic passive continental margin. Southern Alps. Italy. Am. Assoc. Pet. Geol.. 65. Pp. 394-421. 